\title{
Defection and Party Crisis in Nigeria
}

\author{
Ugonma Joy Kalu Ugbor ${ }^{1} \quad$ Ugbor, I. Kalu ${ }^{2} \quad$ Joy Nkiru Agbo $^{1}$ \\ 1.Department of Political Science, University of Nigeria, Nsukka \\ 2.Department of Economics, University of Nigeria, Nsukka
}

\begin{abstract}
Since the creation of political parties in Nigeria, it has been characterized by the issue of defection and party crisis. This had been accompanied by the role of democratic institutions in resolving the problems of defection and party crisis in Nigeria, having in mind that the structure of these democratic institutions could play a significant role in the consolidation of democracy. Hence, the study interrogates how weak democratic institution impacted on defection and party crisis which inversely affects democracy and also examined the link between defection and party crisis. The data was collected through documentary sources on the various indices of corruption, institutional quality, freedom and fragile state of different years from 2008-2017. The data was analyzed using the multiregression analysis. The result shows that lack of peace, and security, corruption, and institutional quality had a negative impact on democracy. So the democratic institutions are weak to enforce the rule of law in the country that will guide the activities of politics in Nigeria. Thus, the study found out that the inter-party crisis leads to fractionalization and defection. We predicated our analysis on the structural-Marxism theoretical framework. Also, it recommends that the constitution should be re-written to ensure the proper definition of defection and ensure sanction and penalty for the bridge of these laws in society.
\end{abstract}

Keywords: Defection, weak institution, party crisis, political institution, political business.

DOI: $10.7176 / \mathrm{JESD} / 10-8-06$

Publication date: April $30^{\text {th }} 2019$

\subsection{Introduction}

One of the main characteristics of a democratic administration is the existence of many political parties. These parties will represent extensive views and ideological orientation of the masses, which will in turn help to champion the democratic process in the state. The parties will engage itself in the political education of the masses, given them the opportunity to involve themselves to vote for those who will represent them in the various post and offices. They are the global lens which the masses used to view the leader's mode of governance because these parties have manifestos and objectives which they intended to achieve before the end of their tenure.

However, the Nigerian political parties were characterized by the issue of defection or decampment and series of party crisis. Nigeria experiences the problem of defection first in 1951 when Dr. Nnamdi Azikiwe of $\mathrm{NCNC}$ has deprived a majority seat at the western region to form a government at the center. Most members of his party defected to Action Group, and at the end, he lost the election. This is to show us, that most of the defection that took place within that period was oriented, towards ethnicity: In 1965 chief. Akintola under the western Regional Electoral crisis broke away from Action Group and went ahead to form NNDP (Nigeria National Democratic party) to win the election which he did.

Also in 1964 Nigeria experience inter-party crisis between Nigeria National Alliance and United Progressive Alliance which involved much electoral violence. During the second and third republic, Nigeria did not experience the issue of party crisis and defection the way it is in the $4^{\text {th }}$ republic. Badejo and Obah-Akpowoghaha (2015) stressed that the party structure and composition, its mode of operation in the society, the way it is fund by Godfathers and the critical issue of decampment could mar the assumed democratic process going on in Nigeria. In other words, if the point of defection and party crisis are not resolved there is going to be a breakdown in the significant pillars of democracy in the society.

Kastina (2016) opines that defection can occur as a result of circumvention of rules and other acts of predictable which can disturb the enthronement of democracy. Also, party crisis can create fractions which can further create decampment, and at the end, there will be an alignment of various parties which can help to form the government at the center with the creation of opposition party. He further analyzed that $40 \%$ of the PDP members decamped to APC when it was created either for one reason or the other. Most members who cannot get party ticket as the flag bearer of that party or for one political post or the other can easily get dissatisfied with the party and move to another party.

Aleyomi (2013) argued that with defection there is no strong opposition choice since most members of the former party come together to form the next party. It leads to lack of clarified ideology, policy and lack of National development in the country. Members of political parties may sometimes look for the fact that the person defected to the present party to get a party ticket. When he wins the election, to achieve the party objectives become a problem. It can also lead to lack of criticism of the government in power. Therefore even when the government is not performing well because of the fact, that is no opposition. The avenue to correct some specific problems in the 
system does not exist.

Nzeagwu (2017) in his own opinion states that defection tends, to promote personal and sectional interest, as well as inter-party crisis. The excitement of most candidates is not about supporting the interests of the masses at hand instead to satisfy their interest first. Most party candidates had seen party politics as an avenue to enrich themselves rather than focusing on the developmental needs of the masses when we look at the significant needs of the masses, which can hardly be met by the government in power both at the federal, state and local level.

Also, the style of leadership had different faces in Nigeria. There is a decline entirely in regulatory roles and functions in society today. Most party candidates had seen a political party entirely as a business venture where individuals put in their money with the aim of making a profit at the end. Moreover, since such is assumed, what is the need of carrying out development in the state.

Defection and party crisis had been at the hallmark of Nigerian politics it had aroused the interest of many scholars and writers. Therefore this study intends to focus on those factors that encourage defection and party crisis in Nigeria.

\subsection{Problem Statement}

Political parties are generally set up in a country to enhance political culture, political socialization and also encourage political and democratic development. They help a lot in forming the government and creating a channel for effective allocation of scarce resources in the society, promoting the rule of law, sector development and through it, the state achieve its primary function of welfarism in the country.

Meisburger (2008) stressed that political party where ever they exit should contribute to the expression of the will of people which will, in turn, encourage their political participation. Moreover, their internal structure and dynamics must be democratic in nature. However, the most important characteristics of a political party could not be seen in Nigeria political parties. Since after independence most parties had toed the line of defection and constant party crisis both intra and inter party crisis. The political parties in Nigeria had eroded their primary function. Their activities in the society instead of encouraging political socialization and cultural development they end up creating political apathy in the citizens. Also, their mode of operation creates fear and insecurity in the country through their threat to their opponents.

Furthermore, they formed factions through their party crisis, and the next event that follows is decampment or defection. Given this situation, most writers had argued that political parties in Nigeria is a business venture and when the business is not working, an alternative is being sought for, either to join another political party for better business or to remain in the present party. Adejuwoon (2013) argued that defection for one purpose or the other had been the pattern of Nigeria politics. It had created a lack of democracy; prevent human capital development, economic stagnation, a rise in poverty level and generally underdevelopment in the country.

Omodia and Egwemi (2011) stressed that political parties had posed an enormous challenge of inaccurate representation in Nigeria polity. Most leaders that had emerged from the political parties had remained the same leaders from the military to a civilian regime. Defection had made it impossible for Nigeria's to have a chance in their leadership style and selection compounded with the issue of party crisis. The crisis had emerged among the recycled leaders together with their political parties thereby creating the atmosphere of insecurity and apathy among the citizens.

Consequently, the main focus of this study is to examine those factors that account for defection and party crisis in Nigeria. Therefore, this work will be guided with the following research questions.

1. Does weak democratic institution encourage party defection and the crisis in Nigeria?

2. Is there any link between the party crisis and defection in Nigeria political parties?

\section{Literature Review}

Part, Burtaine and Buch (2017) argued that developing countries are engulfed with the absence of state institutions that can establish and enforce political party rules to solve public problems. Also, developing countries create agencies without the intention of delivering the actual services. Political parties should function in such a way that their primary function should be established in society. Most political parties cannot create confidence in the minds of citizens as regards election. The laws are there, but responsible authorities don't enforce them effectively enough to bring fairness and justice to the citizens. Also, the absence of state institutions has been blamed for the inability to achieve an entirely democratic government in Nigeria. Due to the activities of these parties, which is usually characterized by violence and crisis, most citizens are denied the opportunity to carry out their civic responsibility of voting. So, weak institution is attributed to failed democracy.

Adamolekun (2008) analyzed that Nigeria is listed among 28 failed and critically weak states. He further examined Nigeria as a fragile state and conflict-affected states, and that weak and failing political institution constitute a significant explanation for state failure. Akubo and (2014) also advocates that lack of expected level of a political institution which had inter and intra party crisis had affected Nigeria ability to grip with its democratic institutionalization. Besides, weak states create a drastically failed government in which citizen cannot justify the 
existence of government in a country. The essential role of government providing welfare becomes vague, and the nation is automatically prone to vicious insecurity cycle of poverty, conflict, anarchy, lack of safety among others. The resultant effect of these above come from a weak institution and if not carefully taken good care of, can move the state into stagnation.

Nwafor and Imaji (2016) stress that the idea of defection and party crisis could be attributed to the long years of military rule which gave these parties poor foundation as to what constitutes the primary function of the political system in a country. The constant change from the parliamentary system to a federal system without due consideration of what constitutes the system. Given the situation from unset the political character of the aspiring candidates depicts that political party is an avenue to harvest the planted mature crops, or where the exchange of goods and services take place in order words a market place. The people were not trained to take up the mantle of leadership with the intention of building a nation. The long years of military rule in Nigeria also showed the long years of colonization. The country experiences a massive capital flight within the period which could have been used to enhance development. Moreover, it also creates an environment of scarcity which citizen in the social struggle through the quest for power to control the existing resources. Also, both colonization and military rule did not encourage institutional development and advancement.

Eme and Ogbochi (2014) stressed on the legal and constitutional basis of political party defection. They argued that the constitution is arranged in such a way that it encourages political parties to defect from one party to another. Onyisi (2005) also analyzed that the law did not incorporate defection and its effect on the democratic process going on in the country. The constitution was prepared to take care of the needs of the politicians in the country, who see defection as their stocking trade which they cannot do without. Most prominent leaders in Nigeria had defected to parties of their choice. Some had defected from PDP to APC or from APC to PDP. Recently the rate of defection had grown so high that it had been the order of the day in Nigeria.

Desposato (2005) opines that defection or party switching anchored on the voting behavior in the country. Each candidate seeks to move as demanded by its consistency and their personal preferences. The main focus of analysis is the individual interest which account for the movement of party members from one party to another. It is being triggered off by the quest to control political power which aimed at managing the country's resources for personal aggrandizement. It is the main character of Nigerian political parties. When a particular party cannot serve the interest of another member, they tend to move in search of another and see if they can be accommodated in other parties. And when that could not happen, they can even move further to another, and this depicts the poverty nature of Nigerians.

Accetti and Wolkenstein (2017) and Omachonu (2018) stressed that lack of internal democracy, leadership crisis in various states account for the intra-party turmoil in Nigeria. Most political parties in Nigeria cannot coordinate and democratize the party leadership style; individuals should be allowed to contest and should be supported to challenge for election within the party. In Nigeria, party members are not given a free hand to operate within their party and to choose their flag bearer democratically. What exists is the imposition of party flag bearers by their party leaders.

Ikechukwu (2015) in his analysis of political parties sees the political parties in Nigeria as being weak and incapable of achieving stability in the society and could not encourage political development and economic prosperity in the country. A weak political party lacked a clear cut ideology, internal peace and could not function well in opposition government. Not only that it cannot produce a democratic government and the ruler needs are not met.

Okparayi (2010) argued that party crisis erupted because of the re-election of candidates, especially those candidates seeking for the tenure of office; as a result, they can defect and even generate crisis within the parts in other to make sure their concerns are accommodated. Despite that Nigeria political parties had a series of problems which geared towards the formation of the government.

In this figure below, weak institution accounts for major problems of Nigerian political parties. It creates party crisis, defection and coalition of parties and the formation of the weak government and authoritarian democracy which is incapable of providing security, warfare to the people among others. 


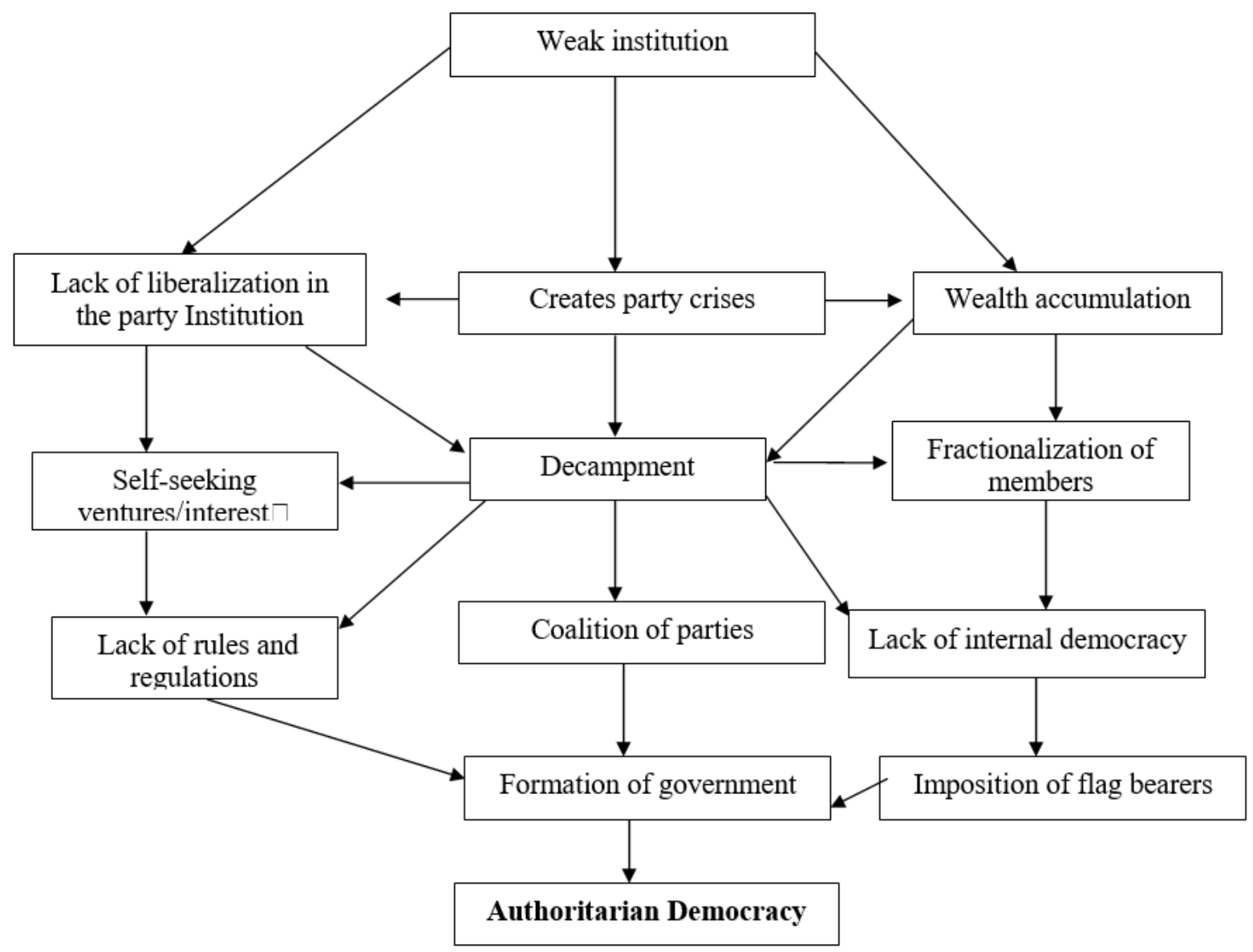

Party crisis often erupted as a result of lack of liberalization of party institution to accommodate most members. Also, the desire for wealth accumulation among member often leads to fractionation, lack of internal democracy, and the imposition of flag bearers. For the fact that there is an emphasis on self-interest there is a lack of rules and regulation guiding the conduct of members in the party.

From the various literature reviewed there is inadequate information as regards to the significant factors that encourage defection and party crisis in Nigeria. However, this study will focus on how weak democratic institution have encouraged party defection and the crisis in Nigerian Democracy from 2008-2017.

\section{Methodology}

\subsection{Statement of Hypotheses}

Ho: Weak democratic institution does not encourage party defection and the crisis in Nigeria

Hi: weak democratic institution encourages party defection and the crisis in Nigeria

\subsection{Theoretical Framework}

The theoretical framework for the study is the structural Marxism developed by the work of the French Philosopher Loues' Althusser. Its primary argument in structuralism was that the institutions of the state must function in such a way as to ensure ongoing capitalism and that the institutions must work to show capitalist society. Moreover, as such the state reproduces the logic of capitalist structure in its economic, legal and political institutions. (Wikipedia 2015) Loius Althusser stresses that the primary goal of the economy is to set boundaries or limits on political and ideological structures but does not specify every political institution nor does it directly determine ideological apparatuses.

Party crisis and defection have its theoretical background on structural Marxism. From our logical point of view, the crisis that erupted within or among parties is mostly, geared towards the acquisition of power and resources in the state. Moreover, capitalist ideology is anchored, on profit maximization and as well as individuals involved in disloyalty is looking for its profit ventures, where they can acquire the resources in a better environment devoid of hostility. Thus, the structures of the state had been built to encourage capitalism.

On the other hand, the state is seen to be weak to embrace the change that is going on the political parties. The political institution has remained adamant and encourages the repressive structure since it is a reflection of the capitalist ideology. In order words, there is a minimal role of democratic institutions in controlling party crisis 
and defection. The whole situation discourages democratic principle and encourages political party in the country.

\subsection{Methods of Data Analysis}

This research used data derived from documentary sources. It examined the significant factors that account for the defection of members from one political party to another from 2008 to 2017 . The rationale for this is to explain the roles of the Nigeria democratic institutions in party defection and crisis which may influence the character or behavior of political parties especially in the area of fulfilling their party manifesto. Also, this research makes use of indices which comprises categories: these are democracy index, peace index, corruption index, institutional quality index, fragile state index. The available index indicates the year 2008 to 2017 and regression tool is used for the analysis.

Table 1: Selected indices

\begin{tabular}{|c|c|c|c|c|c|c|}
\hline Year & Demo index & Peace index & Corruption index & $\begin{array}{l}\text { Institutional } \\
\text { index }\end{array}$ & quality & $\begin{array}{l}\text { Fragile } \\
\text { index }\end{array}$ \\
\hline 2008 & 3.53 & 2.570 & 3.50 & 0.25 & & 0.10 \\
\hline 2009 & 23.71 & 2.599 & 3.50 & 0.23 & & 4.25 \\
\hline 2010 & 3.47 & 2.750 & 3.50 & 0.27 & & 0.40 \\
\hline 2011 & 3.88 & 2.743 & 3.50 & 0.26 & & 0.1 \\
\hline 2012 & 3.77 & 2.801 & 3.50 & 0.25 & & 1.1 \\
\hline 2013 & 3.77 & 2.693 & 3.50 & 0.29 & & 0.8 \\
\hline 2014 & 3.76 & 2.710 & 3.50 & 0.24 & & 0.2 \\
\hline 2015 & 4.62 & 2.910 & 3.50 & 0.23 & & 2.5 \\
\hline 2016 & 4.50 & 2.877 & 3.50 & 0.24 & & 3.6 \\
\hline 2017 & 4.40 & 2.849 & 3.50 & 0.24 & & 1.7 \\
\hline
\end{tabular}

Source authors computation

\subsection{Estimation Technique:}

This study adopted the multi-regression analysis. The primary aim of using multi-regression analysis is to understand how the independent variables are related to the dependent variables (Democracy). The researcher used quarterly data to increase the sample size up to 40 that are appropriate for multi-regression. The procedure for the test is through extrapolation of data of the various indices up to 10 years. The table contains the years, institutional quality index and fragile state index. Also, they are analyzed with the hypothesis.

Table 1; the regression table extrapolated to 10 years

$$
\begin{aligned}
& \text { Thus the regression model; } \\
& \text { Demo }=\mathrm{Bo}+\mathrm{B}_{1} \mathrm{P}+\mathrm{B}_{2} \mathrm{C}+\mathrm{B}_{3} 1+\mathrm{B}_{4}{ }^{\mathrm{F}} \\
& \text { Where } \mathrm{D}=\text { democracy } \\
& \left(\mathrm{b} \mathrm{O}-\text { to } \mathrm{B}_{3}\right)=\text { parameters } \\
& \begin{array}{ll}
\mathrm{P} \quad= & \text { peace } \\
\mathrm{C} & =\text { corruption } \\
\mathrm{I} & =\text { institution quality } \\
\mathrm{F} & =\text { fragile state }
\end{array}
\end{aligned}
$$

\section{Result}

Table 2: Summary of Ordinary least square model. Result for the dependent variable.

\begin{tabular}{lllll}
\hline Variables & Coefficient & Standard error & + statistics & probability \\
\hline Constant & 105.8607 & 32.22715 & 3.28 & 0.017 \\
Peace & -35.0427 & 9.276328 & -3.78 & 0.009 \\
Corruption & -34.50662 & 8.708742 & -3.96 & 0.005 \\
Institution Quality & -33.25231 & 66.19508 & -0.50 & 0.633 \\
Fragile State & 3.235101 & 0.8293155 & 3.90 & 0.008 \\
\hline
\end{tabular}

Source: Computed by the authors

$\mathrm{R}$ - Square $=0.8441$, Adjusted R- square $=0.7662$,

F- Statistics $=10.83$, Prob. $F=0.0078$

Source Author's Compilation

\subsection{Political Interpretation}

Table 2, present the regression results of the relationship between the dependent variable (democracy) and the regressors. It is observed that the constant is positive and significant within the year 2008-2017 under study. Peace index, corruption index and institutional quality, the index has a negative and significant impact on Democracy in 
Nigeria. The results are correctly signed and consistent with the a priori expectation. It showed that a unit change in peace reduces Democracy by -35.0427 in the period under study. A reduction in peace in the country affects its democracy as well as democratic institutions especially political structures in Nigeria. It was concluded in the study that there is inverse and the insignificant relationship between peace and democracy.

The result of the estimation also revealed that corruption has an inverse and significant impact on Democracy. Corruption qualities with negative sign showed that a unit charge in crime reduces Democracy by -34.50602 in the study period. This also shows that corruption has an inverse relationship with Democracy. It was observed that the party members were only interested in sustaining their political positions and they can do that by all means even it involves defecting to other parties. Thus, if corruption increases in society, democracy quality will reduce by -34.50662 under the period of study.

The study further revealed that a unit decrease in the quality of institution affects democracy by -33.25231 . Institutional quality is an attribute of justice. A good institution ensures even development, breeds quality leaders who are interested in welfarism, providing human capital development, infrastructural development and most importantly establish rules and enforce them. In Nigeria as observed insufficient evidence in the clarification of constitutional laws. On defection section 68(ig) of the Nigerian Constitution stated that a legislator that wishes to deferent declare his or her seat vacant and thus it did not provide enough evidence as to what constitutes the defection hence the institution is weak towards the issue of defection. It was also observed that defection had been a tool which the politicians used during elections had remained unchecked because it satisfies their interest of the elite class in Nigeria.

The fragile state is positively related to the dependent variable. This is because it was observed that the Nigeria state under fragility measure had not reached the level that it will attract international concern like most conflictafflicted countries in the world today. Therefore $\mathrm{B}_{1}, \mathrm{~B}_{2}, \mathrm{~B}_{3}$, decreases democracy whereas $\mathrm{B} 4$ will increase democracy quality in Nigeria. However, it is observed that defection and party crises occur because Nigeria is yet to find the way to curb corruption, maintain peace within the ethnic group and change the leadership style and look forward to quality and reliable institution.

\section{Hypothesis II}

There is a link between the party crisis and defection in Nigeria political parties

The researcher observed that there is a link between the party crisis and defection in Nigeria political parties. The inter and intra party crisis usually erupted within the issue of party primaries. Also, election time determine who gets what, how and when. Following the acquisition of state power, party members articulate their primary interest, especially on the viable positions and posts.

Moreover, this can be acquired by all means even if it involves defecting to another party where their investment will be secured. Inside the party, it was observed that many members are not given chances to achieve their interest and for the motive of profiteering members are bound to fight for their benefit. Also, they do this at times by instigating party conflict which will eventually lead to party fractions and then defection.

Further, it was found that democratic institution in Nigeria could not control party rules where they exist talk less of enforcing party internal democracy and preventing party crisis. These rules are highly bridged especially by Godfathers who constantly will like to have their ways in the various parties.

\section{Conclusion}

The role of political parties in championing democracy and political culture has been quietly explored, but little attention has been given to the link between defection and political crisis and how their attitudes and behavior had impacted on the Nigeria democratic process. Stemming from the inability of the democratic institution, to exhibit the rule of law, control of corruption, accountability, the democratic electoral process, human right among others. To examine the impact of defection on democracy, we collected data on the various indices of various years in Nigeria ranging from democracy index, peace index, corruption, institution quality, and fragile state index. The data was analyzed using Multi-regression analysis. The study found out that lack of peace and security, and lack of institutional quality had a negative impact on the Nigeria democracy and fragile state index indicated that Nigeria delicate state nature had not risen to the extent that it will attract international concern like other stateaffiliated areas.

Hence, defection affects the democratic process in Nigeria. The democratic institutions such as the legislature arm forces, judiciary including its parts like the various laws courts, the constitutions among others are fragile. Moreover, it was found that this had lead to a lack of the rule of law, inability of the parties to conduct political education or market their manifestos and hence defection. The study also found out that inter and intra party crisis leads to factionalization and defection. Furthermore, the democratic institution is too weak to take care of these problems as they arise from different parties.

The findings of this study, contribute to the understanding of how weak democratic institutions, should be considered as a core factor, in the development of democracy in Nigeria. The pillars of democracy play an essential 
role in sustaining party democracy as well as instituting it in the country as a whole, and improved or robust institution goes a long way in ensuring justice. Therefore, this study recommends that democratic institutions should provide the development of peace and security in the country, by allowing a free and fair election, the creation of equal opportunity for all the ethnic groups, provides the rule of law and accountability, human right upliftment. Also, parties should remove the issue of Godfarism in their agenda of leadership selection and maintain internal party democracy.

\section{References}

Adejuroon, L. (2013, December $\left.23^{\text {rd }}\right)$. Carpet crossing and old win in New Bottle: New watch, retrieved from htpp://www.Newswatch.ng

Adamolekun, L. (2008, June, 25). Nigeria Tacking the problem of a weak party system. The Vanguard newspaper. Retrieved from http://www/vanguard.ng.

Aleyomi, M. B. (2013). Election and politics of party Defection in Nigeria: A clue from, Kogi State covenant. Journal of Politics and International Affairs, 1(1), $82-84$

Akubo, A. and Umoru, Y.A. (2014). Political parties and Democratic Consolidation in Nigeria's Fourth Republic. Global Journal of political science and administration. 2 (23), 79 - 108

Badejo, B. T. and Obah-Akpowoghaha, N.G. (2015). The impact of cross-carpeting and multicity of political parties in Nigeria democratic process. Journal of African studies and development, 7(8), 215 - 230

Desposato, S.W. (2005). Impact of party switch on the legislative Behaviour in Brazil.

Ikechukwu, U.G. (2015). Parties parallel primaries and its implication to Nigeria development in Nigeria. Developing country studies, 15(10), $109-121$

Accetti, C. I. and Wolkenstein, F. (2017). The crisis of party democracy, cognitive mobilization, and the case for making parties more deliberative. American Political Science Review, 111(1), 97 - 109

Kastvia, A. M. (2013). A Contextual Analysis of party system formation in Nigeria 1960-2011. Journal. intellectual discourse, 21(3),

Meisburger, T. (2008). Methods of promoting internal party democracy in political parties. [Online] retrieved from. Aceproject org/electoral.advice/question/replies.

Nwafor, O.C. and Unaji, F.N. (2016). Party conflict and prospects of Democratic Consolidation in Nigeria. Journal of humanities and social science volume, 21(5), 91

Nzeagwu, U. (April 14 ${ }^{\text {th }}$, 2017). Death of ideology in Nigeria political. The Guardian Newspaper. Retrieved from. http://www/gaurdin.ng.

Okechukwu, E., and Ogbochi Andrew (2014). The legal and constitutional Basis of political party defection. Journal of Business and Management Review, 3(11),

Okparaji, P. (2010 $1^{\text {st }}$ February). Nigeria party, Defection and low. Tide Newspapers retrieved from: http://www newsonline.com.

Omachanu, J. (2018). The intra-party crisis threatens the 2019 election. Independent Newspaper. Retrieve from: https://www.independent.ng./sites/SPS/documents/policy-politics/onyishi.docx.

Onyishi, A.O. (2015). Between man and his institutions: Intra-party politics and future of democracy in Nigeria. Available from: http://www.bris.ac.ukmedialibrary

Part, B. Burtawe, M. and Buch, B. (2017). Why developing countries are stuck with weak institutions and how foreign actors can help. Brooking. Retrieved from: http://www/rooking.edu. 